\title{
Work context, job satisfaction and suffering in primary health care
}

\author{
Contexto de trabalho, prazer e sofrimento na atenção básica em saúde \\ Contexto de trabajo, placer y sufrimiento en la atención primaria de salud
}

\author{
Greisse da Silveira Maissiat ${ }^{\mathrm{a}}$ \\ Liana Lautert ${ }^{b}$ \\ Daiane Dal Paic \\ Juliana Petri Tavares ${ }^{d}$
}

\begin{abstract}
Objective: To evaluate the work context, job satisfaction and suffering from the perspective of workers in primary health care. Method: This cross-sectional study was conducted with 242 employees of a municipality of Rio Grande do Sul, Brazil, from May to July 2012. The adopted instruments were the Work Context Assessment Scale (EACT) and the Job Satisfaction and Suffering Indicators Scale (EIPST). Research also included descriptive and inferential statistical analysis.

Results: Organization (91.3\%) and work conditions (64\%) received the worst scores in terms of context. The indicators of job satisfaction were related to professional achievement (55.8\%), freedom of expression (62.4\%) and recognition (59.9\%). However, 64.5\% presented professional exhaustion, which had an inverse association with age and years in the institution $(p<0.05)$.

Conclusion: The workers evaluated their work context as inappropriate and complained of exhaustion, although they claimed their work affords some satisfaction.
\end{abstract}

Keywords: Occupational health. Working conditions. Job satisfaction. Primary health care.

\section{RESUMO}

Objetivo: Avaliar o contexto de trabalho e os indicadores de prazer e sofrimento na perspectiva de trabalhadores da atenção básica em saúde.

Método: Estudo transversal, que utilizou a Escala de Avaliação do Contexto de Trabalho (EACT) e a Escala de Indicadores de Prazer e Sofrimento no Trabalho (EIPST) com 242 trabalhadores de um município do Rio Grande do Sul, Brasil, de maio e julho de 2012. Fez-se análise estatística descritiva e inferencial.

Resultados: A organização $(91,3 \%)$ e as condições de trabalho (64\%) obtiveram as piores avaliações quanto ao contexto. Os indicadores de prazer no trabalho estiveram relacionados à realização profissional (55,8\%), liberdade de expressão (62,4\%) e reconhecimento (59,9\%). Entretanto, 64,5\% apresentaram esgotamento profissional, o qual obteve associação inversa com a idade e 0 tempo de trabalho $(p<0,05)$.

Conclusão: 0 trabalhador avalia seu contexto de trabalho como impróprio e encontra-se esgotado, contudo possui fontes de prazer no trabalho.

Palavras-chave: Saúde do trabalhador. Condições de trabalho. Satisfação no emprego. Atenção primária à saúde.

\section{RESUMEN}

Objetivo: Evaluar el contexto de trabajo y los indicadores de placer y el sufrimiento desde la perspectiva de los trabajadores de la atención primaria de salud.

Método: Se trata de un estudio transversal que utilizó la Escala de Evaluación del Contexto Trabajo (EACT) y la Escala de Indicadores placer y el sufrimiento en el Trabajo (EIPST) con 242 trabajadores en una ciudad de Rio Grande do Sul, Brasil, mayo y julio 2012. El análisis estadístico fue descriptivo e inferencial.

Resultados: La organización (91,3\%) y las condiciones de trabajo (64\%) tuvieron las peores evaluaciones en el EIPST. Indicadores de placer en el trabajo estaban relacionadas con la satisfacción laboral (55,8 \%), la libertad de expresión (62.4\%) y reconocimiento $(59,9 \%)$, sin embargo, el 64,5\% presentaba agotamiento profesional, que obtuvo asociación negativa con la edad y el tiempo de trabajo $(p<0,05)$.

Conclusión: El trabajador evalúa su contexto de trabajo como no apropiado y está agotado, sin embargo tiene fuentes de placer en el trabajo.

Palabras clave: Salud laboral. Condiciones de trabajo. Satisfacción en el trabajo. Atención primaria de salud.
D0l: http://dx.doi.org/10.1590/1983-

1447.2015.02.51128

a Doctoral degree student of Nursing at the Universidade Federal do Rio Grande. Master of Nursing from the Universidade Federal do Rio Grande do Sul (UFRGS). Nurse at the Prefeitura Municipal de Estrela, Rio Grande do Sul (RS), Brazil.

${ }^{b}$ Doctor of Psychology. Full Professor of the Department of Medical-Surgical Nursing of the School of Nursing at the UFRGS. Porto Alegre, RS, Brazil.

' Doctor of Nursing Practice. Adjunct Professor of the Department of Medical-Surgical Nursing of the School of Nursing at the UFRGS. Porto Alegre, RS, Brazil.

${ }^{d}$ Doctor of Nursing Practice. Professor of the Nursing Course at the Centro Universitário Metodista - IPA Porto Alegre, RS, Brazil. 


\section{DINTRODUCTION}

The changes proposed by health care restructuring to consolidate the Unified Health System (SUS) bring new and constant challenges to health care workers ${ }^{(1)}$. These professionals are required to provide services based on the presumption of comprehensiveness, with humanized actions of listening and openness toward the unique needs of users, which often represents the workers own needs regarding their health in relation to work ${ }^{(2)}$.

In addition to the traditional occupational risks in the field of health (chemical, physical, biological and ergonomic) $)^{(3)}$, the workers who provide primary care must also consider workplace characteristics and the best way to insert themselves into the community. This confrontation with the life standards of users, which is never entirely predictable and always implicit in any health action, is even more intense for these professionals ${ }^{(4)}$.

The close bond between these workers and the territory of their users favours the provision of care that is better adapted to people's lives ${ }^{(1)}$. However, this may also increase the vulnerability of workers to suffering due to the increased sensation of impotence in relation to the "health" problems they must "treat", the fear triggered by threats to their moral and physical integrity when working in open environments or at the homes of users, and the lack of recognition for their efforts at work ${ }^{(5)}$.

The suffering endured by professionals who work in primary care is either caused by the scarcity of problem-solving resources and technologies or by the exacerbation of the value of the curative model(6) - a priori not prevalent in this field and in the rational discourse traditionally valued among professionals. On the other hand, the strategies adopted to consolidate teamwork and the shared planning of activities and mishaps of the work process can be considered ways of benefiting primary care workers in terms of job satisfaction ${ }^{(7)}$.

The study of job satisfaction and suffering is the central proposal of the Psychodynamic Theory chiefly authored by Christophe Dejours ${ }^{(8)}$. This approach argues that there is no neutrality in the relationship between the work and mental health of workers, and that this impact occurs through recognition, which is a pivotal and symbolic benefit for constructing the identity of subjects in society. The health of workers is viewed from the perspective of the dynamics of human relationships at work, which determines the experience of satisfaction and/or suffering under the influence of occupational conditions and organization ${ }^{(9)}$.

The work context refers to the social space where the organizations, work conditions and socio-professional rela- tionships operate. Consequently, the Psychodynamics Theory applied to work addresses the way workers perceive content, pace and distribution of tasks, standards, charges and negotiations; the division, integration, communication and support among people; and the environment, tools and resources available for the production process ${ }^{(9)}$.

Work satisfaction and suffering are experiences that imprint a greater or lesser vulnerability to illness ${ }^{(8-9)}$. According to the Psychodynamics Theory, job satisfaction is based on the perception of professional achievement and freedom of expression. This freedom is defined as the opportunity to express feelings and opinions to colleagues and supervisors, including the experience of confidence, solidarity and cooperation, and the possibility of using creativity at work. Professional achievement is related to the experience of well-being, satisfaction, motivation, recognition and pride for a given work activity ${ }^{(9)}$.

Furthermore, according to the Psychodynamics Theory, suffering at work represents a condition that drives worker mobilization against inconsistencies experienced at work and may even trigger mental disease. Suffering can be evaluated through the experience of exhaustion that is caused by the perception of stress, dissatisfaction, burden, frustration, insecurity or fear. The lack of recognition can also decisively trigger suffering. Workers who feel that their efforts are not appreciated may subsequently experience feelings of anger, helplessness and injustice $e^{(9-1)}$.

Based on the key concepts of the Psychodynamics Theory, and on the results of recent studies on work in primary care ${ }^{(11-13)}$, the aim of this paper is to narrow the knowledge gap on job satisfaction and suffering of workers in this context. The guiding question was: How do workers assess their work context and the indicators of work satisfaction and suffering? The importance of evaluating work contexts and the indicators of job satisfaction and suffering is based on the centrality of workers as the objects of interest in the fields of study and practices of worker health. These evaluations also help to overcome dilemmas related to the consolidation of primary care as a privileged means to establishing the proposals of the Unified Health System.

This article was compiled from the results of a master's dissertation entitled "Prazer e Sofrimento de Trabalhadores da Atenção Básica à Saúde à Luz da Teoria da Psicodinâmica do Trabalho"(14).

\section{METHODOLOGY}

This cross-sectional study was conducted with active primary care health workers of a municipality in Vale do Taquari, interior of the state of Rio Grande do Sul, Brazil. The 
primary care service consists of 15 health units, eight Family Health Strategy teams, four primary care units and three health centres.

The inclusion criterion was workers who had been providing professional primary care for at least six months. The exclusion criterion was workers on leave (maternity, health or others) or on holidays during the period of data collection. After applying the criteria mentioned above, the sample group represented $80.13 \%$ of a population of 302 employees $(n=242)$.

Data were collected from May to July 2012 by means of a questionnaire with questions relating to age, gender, education, marital status, job title, type of contract, time worked at the institution, time worked in the current position, regular medical check-ups, and removal or time away from work. The work context, satisfaction and suffering were evaluated by applying the Work Context Assessment Scale (EACT) and the Job Satisfaction and Suffering Indicators Scale (EIPST). These scales were created according to concepts of the Psychodynamic Theory and make up the Inventory of Work and IIIness Risks ${ }^{(9-10)}$.

The EACT includes the domains of Work Organization, Work Conditions and Socio-professional Relationships, that are graded with a Likert-type scale of five points: $1=$ never, $2=$ rarely, $3=$ sometimes, $4=$ often, and $5=$ always. This classification involves the following assessments: severe (average over 3.7), critical (average between 2.3 and 3.69) and satisfactory (average under 2.3). Data were interpreted for the group of workers by identifying the percentage of subjects for each item.

The EIPST comprises the domains of Professional Achievement, Freedom of Expression, Lack of Recognition and Lack of Freedom of Expression. For the domains Professional Achievement and Freedom of Expression, the higher the average, the greater the feeling of satisfaction. This classification is assessed as positive, or satisfactory (average over 4.0), moderate, or critical (average between 2.1 and 3.9) and rarely, or severe (average of 2.0 or under). The domains Professional Exhaustion and Lack of Recognition express the experiences of suffering at work, and are assessed as severe (average above 4.0), critical (average between 2.1 and 3.9) and satisfactory (average pf 2.0 or under).

All research subjects signed an informed consent statement and answered the data collection instrument individually on site and during their work hours. The project was approved by the Ethics Committee of the Universidade Federal do Rio Grande do Sul on April 26, 2012 (Protocol 22325).

The data were typed into an Excel ${ }^{\oplus}$ spreadsheet and transferred to Statistic ${ }^{\circledast}$ Predictive Analytics Software (PASW by SPSS
Inc., Chicago, USA) version 18.0 for Windows. Cronbach's Alpha was used to check the reliability of the scales.

Continuous variables were described using average, standard deviation or median. Interquartile and categorical ranges were described by absolute and relative frequencies. The test used to compare proportions between the groups were the Pearson's Chi-square (multi-category variables), Chi-square with Yates' correction (dichotomous variables with expected frequency greater than 5) or Fisher's exact test (dichotomous variables with frequency lower than 5 in at least $25 \%$ of the cells).

The scores of the EACT and EIPST and their domains were divided into two groups: Severe/Critical and Satisfactory. The few workers who assessed the domains as severe obtained average scores that were close to the lower boundary of the domain. For this reason, these scores were grouped with the results of workers who classified these domains as critical. Continuous variables were associated using the Pearson correlation coefficients. The adopted significance level was $5 \%(p \leq 0.05)$.

\section{RESULTS}

The workers of the primary care service $(n=242)$ were mostly women (83.1\%), with a companion (74.4\%), and an average age of $38.85 \pm 10.3$ (minimum of 17 and maximum of 62 years).

Most workers $(57.9 \%, n=140)$ had completed their primary and/or secondary education. A total of 64 (26.4\%) were higher education professionals (nurses, doctors, dentists, nutritionists and physical therapists), 55 (22.7\%) worked as nursing assistants/technicians or dental hygiene technicians, 59 (24.4\%) were community health workers, and 48 (19.8\%) were cleaning/administrative assistants or guards.

In terms of work contracts, most of the workers (78.1\%, $\mathrm{n}=189$ ) had been hired by the municipality and a lower portion $(21.9 \%, n=53)$ were outsourced. Years of work in the municipality and years of work at the unit resulted in a median of four (2-9). In the last 12 months, 210 (86.8\%) workers had had a periodic health exam and 51 (20.7\%) had been away from work due to illness.

Chart 1 shows Cronbach's Alpha value, measures of central tendency and risk classification of the Work Context Assessment Scale (EACT) and the Job Satisfaction and Suffering Indicators Scale (EIPST), with the percentages for valid responses.

Analysis of the averages and standard deviation of the questions in each domain of the EACT showed that there were two issues in which Work Organization was assessed 


\begin{tabular}{|c|c|c|c|c|}
\hline \multirow[b]{2}{*}{ Scales Domains } & \multirow[b]{2}{*}{$\begin{array}{c}\text { Cronbach's } \\
\text { Alpha }\end{array}$} & \multirow[b]{2}{*}{$\begin{array}{l}\text { Average } \pm \\
\text { SD* }\end{array}$} & \multicolumn{2}{|c|}{ Risk classification $n(\%)$} \\
\hline & & & $\begin{array}{c}\text { Severe/Critical } \\
\mathbf{n}(\%)\end{array}$ & $\begin{array}{c}\text { Satisfactory } \\
\mathbf{n}(\%)\end{array}$ \\
\hline $\mathrm{EACT}^{+}$ & 0.918 & & & \\
\hline Work Organization $(n=242)$ & 0.764 & $3.12 \pm 0.61$ & $221(91.3)$ & $21(8.7)$ \\
\hline Work Conditions $(n=242)$ & 0.892 & $2.65 \pm 0.91$ & $155(64)$ & $87(36)$ \\
\hline Socio-professional Relations $(n=208)$ & 0.856 & $2.30 \pm 0.79$ & $121(59.8)$ & $87(40.2)$ \\
\hline EIPST $^{*}$ & 0.837 & & & \\
\hline Professional Achievement $(n=240)$ & 0.932 & $4.04 \pm 1.42$ & $105(43.7)$ & $135(56.3)$ \\
\hline Freedom of Expression $(n=240)$ & 0.898 & $4.33 \pm 1.63$ & $89(37.1)$ & $151(62.9)$ \\
\hline Professional Exhaustion $(n=240)$ & 0.887 & $4.27 \pm 1.40$ & $156(65.0)$ & $84(35.0)$ \\
\hline Lack of Recognition $(n=240)$ & 0.927 & $1.87 \pm 1.65$ & 95 (39.6) & $145(60.4)$ \\
\hline
\end{tabular}

Chart 1 - Distribution of scores for workers of the primary care service for the domains of the Work Context Assessment Scale and the Job Satisfaction and Suffering Indicators Scale. Porto Alegre, 2013

Source: Maissiat GS. Direct collection of data using a questionnaire, 2012.

*SD (standard deviation); 'EACT (Work Context Assessment Scale); :EIPST (Job Satisfaction and Suffering Indicators Scale)

as severe: "the tasks are repetitive" and "the number of people is insufficient to perform the tasks". The other issues were evaluated as critical. For the domain Working Conditions, all the items were assessed as critical. In contrast, for the domain Socio-Professional Relationships $50 \%$ of the questions were marked satisfactory.

For the domain Professional Achievement of the EIPST, three issues were assessed as critical: "motivation", "appreciation" and "recognition". Four of the eight questions that made up the domain Lack of Recognition were assessed as satisfactory, and all of the questions in the domain Freedom of Expression were considered satisfactory. Howev$\mathrm{er}$, in the domain Professional Exhaustion the questions regarding 'insecurity' and 'fear' were classified as serious, while the remaining question were classified as critical.

Based on the presumption that work context is a determinant of the workers' experience of satisfaction and suffering, chart 2 shows the association between areas of the EACT and EIPST and their correlation coefficients.

The distribution of the sociodemographic and professional variables showed no statistical difference between the variable 'profession' in the domain Work Organisation $(p=0.04)$, with a higher proportion of the option 'severe' among the community health workers (96.6\%).

The domain Socio-professional Relationships of the EACT resulted in a similar assessment. However, there was a statistically significant difference between the groups $(p=0.036)$. This difference was higher among higher education professionals - nurses, doctors, dentists, nutritionists and physical therapists. Moreover, there was a predom- inance of the option 'satisfactory' (64.6\%) between the cleaning and administration assistants and the guards.

The domain Professional Realization of the EIPST showed a significant difference for the variable 'age' ( $p=$ $0.025)$, being that the average age of workers with a severe/critical assessment was lower $(37.0 \pm 9.9)$ than those who chose the option 'satisfactory' (40.1 \pm 10.3$)$.

In the domain Professional Exhaustion of the EIPST, there was a statistical difference with age $(p=0.002)$, being that the assessment severe/critical was selected by subjects with the lowest age average (37.2 years). The same domain also presented a statistical difference with occupation ( $p=0.037$ ), being that $75.9 \%$ of the community health workers and $71.9 \%$ of the health care professionals (nurses, doctors, dentists, nutritionists and physical therapists) evaluated this domain as severe/critical. Furthermore, there was an inverse association of Professional Exhaustion with years working at the institution ( $p=0.025)$, being that the workers with less time at the institution selected the most negative assessments.

\section{DISCUSSION}

Work Organization, which is defined as the arrangement of standards, controls, work pace, work days, hierarchy, division of work and activities, management models and responsibilities ${ }^{(9)}$, is one of the domains of the Work Context Assessment that the primary care workers assessed as being critical. This evaluation was linked to pressure regarding deadlines and results, an insufficient number of people to 


\begin{tabular}{|c|c|c|c|c|c|c|c|c|c|}
\hline & \multicolumn{9}{|c|}{ Scales } \\
\hline & \multirow{2}{*}{\multicolumn{2}{|c|}{ Domains $^{\dagger}$}} & \multicolumn{3}{|c|}{ Work Context Assessment - EACT } & \multicolumn{4}{|c|}{ Job Satisfaction and Suffering Indicators - EIPST } \\
\hline & & & wo & WC & SPR & PA & PE & $\mathbf{F E}$ & LR \\
\hline \multirow{7}{*}{$\underset{\underline{E}}{\mathbb{E}}$} & - & $\mathrm{WO}^{\ddagger}$ & - & & & & & & \\
\hline & 缁 & $W C^{\S}$ & $0.491^{*}$ & - & & & & & \\
\hline & & SPR" & $0.496^{*}$ & $0.575^{*}$ & - & & & & \\
\hline & \multirow{4}{*}{ 占 } & $P A^{9}$ & $-0.201^{*}$ & $-0.404 *$ & $0.408^{*}$ & - & & & \\
\hline & & $P E^{* *}$ & $0.427^{*}$ & $0.364^{*}$ & $0.382^{*}$ & $-0.327^{*}$ & - & & \\
\hline & & $\mathrm{FE}^{\mathrm{tt}}$ & $-0.039^{*}$ & $-0.265^{*}$ & $-0.351^{*}$ & $0.626^{*}$ & $-0.094^{*}$ & - & \\
\hline & & $L R^{\neq \neq}$ & $0.320^{*}$ & $0.419^{*}$ & $0.466^{*}$ & $-0.405^{*}$ & $0.696^{*}$ & $0.235^{*}$ & - \\
\hline
\end{tabular}

Chart 2 - Association between the domains of the Work Context Assessment Scale and the Job Satisfaction and Suffering Indicators Scale. Porto Alegre, 2013

Source: Maissiat GS. Direct collection of data using a questionnaire, 2012.

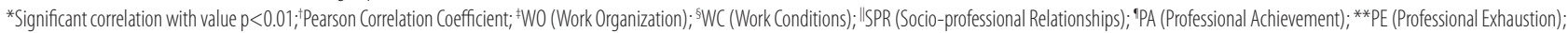
HFE (Freedom of Expression); \#

carry out the activities, repetitive tasks, and an accelerated work pace, among others, all of which are determinants of suffering for workers.

Similarly, in the Family Health Strategy team from Brasília, Distrito Federal, Brazil, this domain was also assessed as critical ${ }^{(11)}$. The nurses of the primary care unit in a city in the interior of Rio Grande do Sul claimed that they were frustrated by their inability to provide quality care due to the high work demands ${ }^{(2)}$.

As for the domain Socio-professional Relationships, it should be noted that the negative assessment was the result of lack of autonomy, lack of integration in the workplace, lack of support from senior management for professional development, unsatisfactory communication and the exclusion of workers in work-related decisions. Similar findings were recorded in a study conducted with the same public of professionals, which reveals minimally controlled self-perception and few decision-making opportunities at work ${ }^{(12)}$. The strong hierarchical system and the division of activities cause workers some suffering, as they tend to be excluded from the production process at work. This exclusion eventually leads to lesser cooperation, which negatively affects good health ${ }^{(9)}$.

On the other hand, in the domain of Socio-professional Relationships the distribution of tasks was assessed as being satisfactory and was considered clearly defined and fair, with easy access to information for their execution. This could be attributed to the availability of protocols and highly detailed assistance programmes. A study conducted with community health workers of a Family Health Strategy unit in a municipality of southern Brazil revealed the exis- tence of modes of action and know-how that are very different and a lot more detailed than those provided in the manuals that supposedly guide the activities of workers ${ }^{(4)}$.

The conditions for completion of work were considered critical by workers mainly with regard to inadequate furniture, excessive noise, lack of instruments and materials. These data indicate inconsistencies regarding the execution of tasks in the primary care service ${ }^{(11.13)}$, which contribute to the suffering.

This may suggest that the demands that are often experienced due to the discrepancy between prescribed and real work, the employees chose to quicken their own pace as a defence strategy that helps them dissociate the experience of suffering(9) in order to keep working. Maintaining this effort for extended periods without prospects of change could become a burden and have negative effects on the health of workers. The percentage of workers in this study who were away from work due to illness in the last 12 months suggests that suffering caused by work demands is not being successfully tackled with the defence strategies, which also affects the health of workers.

According to the European Agency for Safety and Health at Work ${ }^{(15)}$, the organisation and management of work and its social and environmental contexts have the potential to cause psychological, social and/or physical harm to workers. Nevertheless, the organisation of work is a result of the intersubjective and social relationship of workers with organizations ${ }^{(8)}$, that is, it requires interactions between the environment, content, nature and conditions of work, and the capabilities, needs and conditions of the worker's life, as also established by the International Labour 
Organization ${ }^{(16)}$. The outcome of these interactions may pose psychosocial risks capable of affecting the health, efficiency and job satisfaction of workers.

The evaluation of job satisfaction and suffering indicators showed a prevalence of Professional Exhaustion, which did not include any items that were classified as satisfactory by the subjects. Burden and stress issues reached the highest averages in this assessment, which reveals that the primary care workers experienced suffering. This can be explained by the correlation of these issues with the assessment of Organization and the Work Context.

In addition, Professional Exhaustion can be linked to the isolation and submission caused by threats made by some users that workers consider violent $(5,17)$, which adds to the insecurity and stress of coping with the deaths, illnesses and threats these workers experience during their workday ${ }^{(18)}$. Another study revealed an association between conflict with users and a bad work environment ${ }^{(12)}$.

The feeling of insecurity among workers of a Family Health Strategy has been related to social and family conflicts ${ }^{(17)}$ in their daily work. The emotional distress of community health workers ${ }^{(19)}$ is caused by the home visits to neighbours, family members and/or persons with whom they have had conflicts. As community health workers live and work in the same community and know the people and events of that area, they build close bonds and are susceptible to emotional involvement. By witnessing the suffering of users ${ }^{(18)}$ they also assume the mental burden that can lead them to the professional exhaustion detected in this study.

During the evaluation of Job Satisfaction and Suffering indicators, the domains Professional Achievement, Freedom of Expression and Recognition were assessed as satisfactory. This suggests that, despite the weaknesses of the organization and the work context, these workers do find pleasure in their work. The fact that they like their work positively affects professional performance and organisation of their work (2). Moreover, their close relationship with the community often makes their work more meaningful(20). A similar finding was recorded in a study with workers of a nursing unit in a Family Health Strategy and a hospital. In this study, the recognition of senior management was exclusively related to productivity, compliance with goals and demands of the work organisation. However, recognition from the users could be considered decisive to minimize professional exhaustion ${ }^{(13)}$.

In this study, the questions that the workers considered satisfactory were related to well-being, professional achievement, personal gratification for their activities, pride in their work, and satisfaction and identification with tasks.
Professional Achievement was linked to identification with the activities, that is, it is a state of pleasure resulting from the positive assessment of the work performed that, in accordance with public service policies, benefits the workers' inclusion and awareness regarding their work(20).

Freedom of Expression was also assessed as satisfactory by the workers. This assessment is similar to findings in the study conducted at the Family Health Strategy, where the workers assessed all the items of this domain as being satisfactory ${ }^{(11,18)}$. However, the item "freedom with senior management to negotiate what is needed" was considered critical. This reveals that although the workers have the freedom to express themselves in their work group, they feel they do not have this freedom to negotiate with senior management.

At the primary care service in municipalities of the metropolitan region of Rio de Janeiro, high scores of dissatisfaction where recorded in the assessments of relationships with senior management and colleagues ${ }^{(12)}$. A study with community health workers revealed that these workers act as producers of meaning and micromanagement of the work process at the Family Health Strategy, in addition to actively participating in the decision-making processes ${ }^{(4)}$.

Although satisfactory, the domain Lack of Recognition was assessed as critical in four of the eight questions, namely "lack of recognition for my efforts" "lack of recognition for my performance", "devaluation" and "indignation", all of which can cause suffering and enhance professional exhaustion. Similarly, although Professional Achievement was assessed as satisfactory for most of the workers, the results showed that suffering is caused by the lack of motivation, appreciation and recognition for their efforts.

Considering the risks that feelings of disregard and negative emotions may represent to the health of workers, factors that are considered health risks should be identified in order to create intervention measures that protect workers. Collective thought and discussion on how the working process is organized and on the difficulties and challenges of daily work routines are critical in the fight against suffering at work caused by the lack of recognition and the lack of appreciation ${ }^{(13)}$.

The crossing of data of the domains with the sociodemographic and professional variables of the workers revealed that Freedom of Expression was considered satisfactory by a higher percentage of workers with primary and secondary education than by workers with a higher education. This result could be related to the work characteristics of these professionals (nurses, doctors, dentists, nutritionists and physical therapists). In addition to performing the activities inherent to their professions, they 
must assume positions of leadership and team coordination, which sometimes inhibits the free expression of their opinions to colleagues or senior managers.

The professional exhaustion of the workers in this study is mitigated by their experience and maturity. Exhaustion was inversely proportional to the number of years at the institution and the age of workers. This reveals that workers seem to develop a defensive strategy to deal with the conflicting situations and demands of work. The influence of age on emotional strain and depersonalization was identified among employees of the Family Health Strategy of Santa Maria, Rio Grande do Sul, Brazil, and attributed to the inexperience of the youngest workers in dealing with their work and the shock of confronting reality ${ }^{(20)}$.

When the workers begin their careers they are generally young and critical in relation to work, and have high expectations regarding their performance. When these expectations are not reached, they tend to experience feelings of professional frustration and subsequent exhaustion. Their fear of unemployment, however, often leads them to trivialize this physical and psychological strain. It is therefore imperative to help workers of all ages mitigate these problems and consequently protect their health. As revealed in this study, recognition and freedom of expression are strategies that boost professional achievement and reduce exhaustion.

\section{- CONCLUSION}

Data obtained from the Work Context Assessment Scale showed that workers of the primary care service evaluated organization and work conditions as being inappropriate in most of the defining aspects. Data from the Job Satisfaction and Suffering Indicators Scale showed that professional achievement, recognition and freedom of expression are sources of satisfaction at work, and that professional exhaustion is indicative of suffering.

It was possible to conclude that professional exhaustion and freedom of expression were inversely proportional to the age of workers, which shows that primary care service workers build defensive strategies against suffering with time. There was a significant correlation between the domains Professional Achievement, Professional Exhaustion and Lack of Recognition, and Work Organization, which indicates the positive interference of work organisation on job satisfaction at the primary care service.

Finally, we recommend that managers and workers join forces to restandardize work organization and conditions in order to create measures that reduce suffering and increase the sources of pleasure at work. This study will hopefully contribute to improving local services and the construction of knowledge on the health of workers at the primary care services, given the central role of this care modality for the advancement of health care systems and its potential for causing both pleasure and suffering among its protagonists.

The limitations of this study are the lack of a deeper subjective and intersubjective understanding of primary care workers when assessing their satisfaction and suffering at work, and the prevalence bias that is characteristic of studies with a temporal cross-sectional approach. We therefore suggest the conduction of longitudinal studies or the application of action research methodology proposed by the Psychodynamic Theory.

\section{DEFERENCES}

1. Gomes KO, Cotta RMM, Araújo RMA, Cherchiglia ML, Martins TCP. Atenção primária à saúde - a "menina dos olhos" do SUS: sobre as representações sociais dos protagonistas do Sistema Único de Saúde. Ciênc Saúde Colet. 2011;16(Supl 1):881-92.

2. Schrader G, et al. Trabalho na unidade básica de saúde: implicações para a qualidade de vida dos enfermeiros Rev Bras Enferm. 2012 mar/abr;65(2):222-8.

3. Souza MCMR, Freitas MIF. Representações de profissionais da atenção primária sobre risco ocupacional de infecção pelo HIV. Rev Latino-Am Enferm. 2010;18(4):[8 telas].

4. Silva-Roosli ACB, Athayde M. Gestão, trabalho e psicodinâmica do reconhecimento no cotidiano da Estratégia de Saúde da Família. In: Assunção AA, Brito J, organizadoras. Trabalhar na saúde: experiências cotidianas e desafios para a gestão do trabalho e do emprego. Rio de Janeiro: Ed. Fiocruz; 2011. p.67-82.

5. Lancman $S$, et al. Repercussions of violence on the mental health of workers of the Family Health Program. Rev Saúde Pública. 2009;43(4):682-88.

6. Van Stralen CJ, et al. Percepção dos usuários e profissionais de saúde sobre atenção básica: comparação entre unidades com e sem saúde da família na região centro-oeste do Brasil. Cad Saúde Pública. 2008;24(1):148-58.

7. Silva $A C B$, Athayde M. 0 programa de saúde da família sob o ponto de vista da atividade: uma análise das relações entre os processos de trabalho, saúde e subjetivação. Rev Bras Saúde Ocup. 2008;33(117):23-35.

8. Heloani R, Lancman S. Psicodinâmica do trabalho: o método clínico de intervenção e investigação. Rev Produção. 2004;14(3):77-86.

9. Mendes AM. Psicodinâmica do trabalho: teoria, método e pesquisa. São Paulo: Casa do Psicólogo; 2007

10. Anchieta VCC, et al. Trabalho e riscos de adoecimento: um estudo entre policiais civis. Psic: Teor Pesq. 2011;27(2):199-208.

11. Shimizu HE, Carvalho Junior, DA. 0 processo de trabalho na Estratégia Saúde da Família e suas repercussões no processo saúde-doença. Ciênc Saúde Colet. 2012;17(9):2405-14.

12. David HMSL, et al. Organização do trabalho de enfermagem na atenção básica: uma questão para a saúde do trabalhador. Texto Contexto Enferm. 2009;18(2):206-14.

13. Kessler Al, Krug SBF. Do prazer ao sofrimento no trabalho da enfermagem: 0 discurso dos trabalhadores. Rev Gaúcha Enferm. 2012;33(1):49-55. 
14. Maissiat GS. Prazer e sofrimento de trabalhadores da atenção básica à saúde à luz da teoria da psicodinâmica do trabalho [dissertação]. Porto Alegre (RS): Escola de Enfermagem, Universidade Federal do Rio Grande do Sul; 2013.

15. Agência Europeia para a Segurança e Saúde no Trabalho (SP). Inquérito europeu às empresas sobre riscos novos e emergentes. Bilbao; 2010 [cited in 2014 dez 10]. Available at: https://osha.europa.eu/pt/publications/reports/pt_esener1-summary.pdf.

16. Organización Internacional del Trabajo (SW). Riesgos emergentes y nuevos modelos de prevención en un mundo de trabajo en transformación. Ginebra; 2010. 22p.
17. Fernandes JS, et al. The effects of professional factors on the quality of life of family health team nurses. Rev Esc Enferm USP. 2012;46(2):404-12.

18. Lopes DMQ, et al. Community health agents and their experiences of pleasure and distress at work: a qualitative study. Rev Esc Enferm USP. 2012;46(3):633-40.

19. Trindade $L L$, et al. Cargas de trabalho entre os agentes comunitários de saúde. Rev Gaúcha Enferm. 2007;28(4):473-9.

20. Trindade $L L$, Lautert $L$. Syndrome of Burnout among the workers of the strategy of health of the family. Rev Esc Enferm USP. 2010;44(2):274-9.
Author's address:

Liana Lautert

Rua São Manoel, 963, Rio Branco

90620-110 Porto Alegre - RS

E-mail: lilabem@gmail.com
Received: 22.10.2014

Approved: 02.04.2015 